\title{
AKTY PRAWA MIEJSCOWEGO W GMINIE I ICH ZNACZENIE DLA BEZPIECZEŃSTWA EKOLOGICZNEGO
}

\begin{abstract}
WSTĘP
Tradycje samorządu terytorialnego w Polsce ukształtowały się na przestrzeni wielu wieków. U podstaw jego powstania leżała potrzeba utworzenia administracji lokalnej, która zapewni skuteczną realizację zadań, a jednocześnie będzie wyłączona ze struktur władz centralnych. Z punktu widzenia współczesnej administracji samorządowej warto zwrócić uwagę na okres Polskiej Rzeczpospolitej Ludowej, w którym występowały wzmożone tendencje centralistyczne oraz lata 90. XX w., które przyniosły szereg przemian demokratycznych, a co za tym idzie, także decentralizację władzy publicznej.

Procesy decentralizacyjne objęły władze publiczne w różnych aspektach, w tym także przypisanej jej funkcji prawotwórczej. Zarówno Konstytucja RP z 1997 roku, jak również ustawodawstwo zwykłe upoważniając organy samorządu terytorialnego do stanowienia aktów prawa miejscowego urzeczywistniły ten proces, czyniąc go zgodnym z prawem. Prawo miejscowe stało się źródłem prawa powszechnie obowiązującego $i$ istotnym elementem całego systemu prawa ${ }^{1}$.

Jak zwraca uwagę Z. Niewiadomski, konstrukcja teoretyczna samorządu jest potrzebna i stanowi nieodłączny element instytucjonalnego systemu państwa demokratycznego. Trudno zgodzić się ze stwierdzeniem, że sama idea samorządu terytorialnego ulega dezaktualizacji, natomiast warto poddać pod zastanowienie,
\end{abstract}

Mgr Izabela Stańczuk - asystent w Katedrze Historii i Teorii Prawa, Instytut Prawa, Akademia Sztuki Wojennej, Al. gen. A. Chruściela „Montera” 103, 00-910 Warszawa-Rembertów; e-mail: i.stanczuk@akademia.mil.pl; https://orcid.org/0000-0003-2446-8428

${ }^{1}$ D. DĄBEK, Prawo miejscowe samorząu terytorialnego, Bydgoszcz-Kraków: Oficyna Wydawnicza Branta 2003, s. 96. 
czy kwestie związane z jego organizacją i funkcjonowaniem odpowiadają potrzebom współczesnego państwa².

Gmina jest podstawową jednostką samorządu terytorialnego, co wynika z art. 164 Konstytucji RP. Konsekwencją tej regulacji jest nałożenie na nią szerokiego katalogu zadań, w którym mieszczą się wszystkie sprawy publiczne o znaczeniu lokalnym, niezastrzeżone ustawami na rzecz innych podmiotów.

Szczególne miejsce w obszarze działalności organów gminy, zajmuje ochrona środowiska, czy też stanowiąc szerzej - bezpieczeństwo ekologiczne. W publikacji skupiono się na stanowionych przez organy gminy aktach prawa miejscowego, gdyż to właśnie one pozwalają przenieść postanowienia aktów prawa powszechnie obowiązującego na „grunt lokalny”. Niniejsza publikacja stanowi próbę przybliżenia się do odpowiedzi na pytanie: jakie jest znaczenie aktów prawa miejscowego stanowionych przez organy gminy dla zapewnienia jej bezpieczeństwa ekologicznego? Treść artykułu skupia się na aktach prawa miejscowego jako źródłach prawa powszechnie obowiązującego, stanowiącego istotne narzędzie w zapewnieniu bezpieczeństwa ekologicznego gminy. Celem pracy jest próba oceny znaczenia aktów prawa miejscowego w realizacji zadań gminy związanych z zagwarantowaniem jej bezpieczeństwa ekologicznego. Powyższa problematyka zaprezentowana została zarówno w ujęciu prawnym, jak i praktycznym popartym przykładami. Jako że katalog zadań gminy wykonywanych na rzecz bezpieczeństwa ekologicznego jest mocno rozbudowany, posłużono się jedynie wybranymi aktami prawa miejscowego. Podstawową metodą jaką zastosowano była metoda dogmatyczno-prawna.

\section{PRAWO MIEJSCOWE W POLSKIM PORZĄDKU PRAWNYM}

W literaturze przedmiotu wskazuje się na złożoność pojęcia „prawa miejscowego". Elementem, który ułatwia jego zrozumienie są pewne, wyodrębnione kryteria podziału, a wśród nich: zakres terytorialnego obowiązywania, podmiot stanowiący to prawo oraz charakter prawny tych aktów. Mówiąc o zakresie terytorialnego obowiązywania prawa miejscowego należy mieć na względzie, że są to akty prawne, których obowiązywanie jest ograniczone do określonego obszaru państwa. Katalog organów, które mogą je stanowić ma zróżnicowany charakter (będą to zarówno organy terenowe, jak i centralne), podobnie jak zróżnicowany jest charakter prawny tych aktów (akty prawa powszechnie obowiązującego i wewnętrznego). Zgodnie z drugim kryterium: podmiotu stanowiącego - prawo do

${ }^{2}$ Z. Niewiadomski, Geneza i istota samorzadu terytorialnego. Przeksztatcenia instytucji, [w:] http://www.wspia.eu/file/15731/15-niewiadomski_pl.pdf [dostęp: 8.04.2019]. 
stanowienia przepisów miejscowych przynależy do organów lokalnych i nie jest tu istotne, jaki jest charakter danego aktu (czy powszechnie obowiązujący czy wewnętrzny). Trzecie kryterium opiera się na charakterze prawnym tych aktów i zawęża rozumienie pojęcia „prawa miejscowego" do aktów stanowionych przez organy lokalne i mających charakter powszechnie obowiązujący. Dla przybliżenia pojęcia "prawa miejscowego" istotne wydaje się również wskazanie na pewien katalog cech, które pozwalają wyróżnić je na tle innych aktów normatywnych. Zaliczono do nich możliwość normowania postępowania wszelkich kategorii adresatów, konieczność istnienia upoważnienia ustawowego do wydania aktu i przekazania go organowi nadzoru oraz obowiązek jego właściwego ogłoszenia ${ }^{3}$.

Jak określa polski ustrojodawca, stanowienie prawa powszechnie obowiązującego mieści się w kompetencjach władzy ustawodawczej oraz wykonawczej. Podział ten nie jest jednak wyczerpujący, albowiem istnieją jeszcze inne kategorie podmiotów, które również korzystają z tego typu uprawnień, z zastrzeżeniem, że stanowione przez nie prawo ma ograniczony zasięg obowiązywania. Podmiotami tymi są m.in. organy samorządu terytorialnego, traktowane nie tylko jako adresaci norm prawnych, ale także pełnoprawni uczestnicy stanowienia tego prawa ${ }^{4}$.

Jak reguluje art. 87 ust. 2 Konstytucji RP akty prawa miejscowego są źródłami prawa powszechnie obowiązującego na obszarze działania organów, które je ustanowiły. Drugą grupę organów, które obok samorządu terytorialnego stanowią prawo miejscowe tworzą terenowe organy administracji rządowej. Co istotne, ustanawianie aktów prawa miejscowego musi odbywać się na podstawie i w granicach upoważnień zawartych $\mathrm{w}$ ustawie. Zasady i tryb ich wydawania zostały uregulowane ustawowo ${ }^{5}$. Wskazany przepis ma charakter normy blankietowej. Brak w nim odniesienia do konkretnych podmiotów, które są uprawnione do stanowienia aktów prawa miejscowego, ustawa zasadnicza nie określa również formy prawnej tych aktów ${ }^{6}$. Jak zwraca uwagę W. Skrzydło, Konstytucja w sposób dość powściągliwy odnosi się do kwestii związanych z aktami prawa miejscowego, pozostawiając tę materię do uregulowania w drodze ustawowej ${ }^{7}$. Ponadto, o tym czy uchwała bądź zarządzenie stanowią akt prawa miejscowego nie decyduje bez-

${ }^{3}$ B. Dolnicki, Samorzad terytorialny, Warszawa: Lex a Wolters Kluwer business 2012, s. 288.

${ }^{4}$ W. Kisiel, Ustrój samorządu terytorialnego w Polsce, Warszawa: Wydawnictwo Prawnicze LexisNexis 2003, s. 81.

${ }^{5}$ Konstytucja Rzeczypospolitej Polskiej z dnia 2 kwietnia 1997 r., Dz. U. Nr 78, poz. 483 z późn. zm., art. 94.

${ }^{6}$ M. Chmas, G. Herc, Akty prawa miejscowego organów samorządu terytorialnego oraz procedura uchwałodawcza, [w:] Ustrój samorządu terytorialnego w Polsce, red. M. Chmaj, Warszawa: Wydawnictwo Prawnicze LexisNexis 2007, s. 186.

${ }^{7}$ W. SkrzydŁo, Konstytucja Rzeczypospolitej Polskiej. Komentarz, Warszawa: Oficyna a Wolters Kluwer business 2009, s. 103. 
pośrednio sama ich nazwa rodzajowa, ale każdorazowo konieczne jest sprawdzenie, czy spełniają one kryteria przewidziane dla tego rodzaju aktu z uwzględnieniem ich specyfiki przedmiotowej lub podmiotowej ${ }^{8}$. Należy pamiętać również, że system źródeł prawa przewidziany przez Konstytucję RP, a obejmujący także akty prawa miejscowego ma charakter zamknięty. Samorząd terytorialny nie dysponuje „autonomią prawodawczą” stanowiąc prawo wyłącznie w oparciu o upoważnienie wynikające z ustawy ${ }^{9}$. Trybunał Konstytucyjny w swoim orzecznictwie zwrócił uwagę na różnicę w upoważnieniu do wydawania rozporządzeń i stanowienia aktów prawa miejscowego. „Rozporządzenia są wydawane na podstawie szczegółowych upoważnień zawartych $\mathrm{w}$ ustawie $\mathrm{i} \mathrm{w}$ celu jej wykonania, natomiast akty prawa miejscowego są stanowione na podstawie upoważnień i $\mathrm{w}$ granicach zawartych w ustawie. Upoważnienie do wydania aktu prawa miejscowego może zatem mieć szerszy zakres, nie musi spełniać wymogu szczegółowości, ani zawierać wytycznych dotyczących treści aktu prawa miejscowego. Organy samorządu terytorialnego, a także administracji rządowej, posiadają zatem szerszy zakres swobody przy stanowieniu prawa niż organy wydające rozporządzenia" 10 .

Organy samorządu terytorialnego $\mathrm{w}$ procesie stanowienia prawa korzystają z władztwa publicznego, a co za tym idzie - ich prawodawstwo musi spełniać określone wymogi i podlega pewnym ograniczeniom. Przede wszystkim, co już zostało wspomniane, mogą stanowić prawo wyłącznie w oparciu o upoważnienia ustawowe i w granicach przez nie zakreślonych. Prawo to poddane jest regulacjom przewidzianym dla prawa powszechnie obowiązującego, a ustanowienie każdego aktu wymaga wskazania każdorazowo podstawy prawnej ${ }^{11}$. Uwzględniając rodzaj upoważnienia ustawowego do wydania przepisu można wyróżnić trzy grupy aktów prawa miejscowego: akty, które są stanowione na konkretnej podstawie, stanowione na podstawie delegacji ujętej w przepisach szczególnych oraz te, dla których upoważnienia zawarto w regulacjach ustrojowych. Mając na uwadze przeznaczenie przepisów prawa miejscowego, którym jest uszczegółowienie treści ustaw, warto podkreślić, że ustawy szczególne mogą zawierać upoważnienie do fakultatywnego lub obligatoryjnego stanowienia aktów prawa miejscowego ${ }^{12}$.

\footnotetext{
${ }^{8}$ P. WinczoreK, Komentarz do Konstytucji Rzeczypospolitej Polskiej z dnia 2 kwietnia 1997 roku, Warszawa: Liber 2008, s. 220.

${ }^{9}$ R. Doganowski, Ustrój i zadania samorządu terytorialnego, Sulechów: Wyższa Szkoła Zawodowa Administracji Publicznej w Sulechowie 2001, s. 88.

${ }^{10}$ Wyrok Trybunału Konstytucyjnego z dnia 8 lipca 2003 r., sygn. akt P10/02, poz. 62, s. 4.

${ }^{11}$ K. Bandarzewski, P. Chmielnicki, W. Kisiel, Prawo samorzadu terytorialnego $w$ Polsce, Warszawa: Wydawnictwo Prawnicze LexisNexis 2006, s. 146.

${ }^{12}$ M. Baron-Wiaterek, Prawo miejscowe jako podstawa funkcjonowania spoleczności lokalnej - wybrane aspekty, „Zeszyty Naukowe Politechniki Śląskiej” 76 (2014), s. 191.
} 
Warunkiem wejścia w życie aktu prawnego jest jego ogłoszenie. Zgodnie z art. 13 pkt 3 ustawy z dnia 20 lipca 2000 r. o ogłaszaniu aktów normatywnych i niektórych innych aktów prawnych, akty prawa miejscowego stanowione przez organ gminy ogłaszane są w wojewódzkich dziennikach urzędowych. Regulacje tej samej ustawy stanowią, że przepisy porządkowe ogłaszane są ponadto w drodze obwieszczeń oraz w sposób zwyczajowo przyjęty na danym terenie lub w środkach masowego przekazu. Termin wejścia w życie aktu normatywnego zawierającego przepisy powszechnie obowiązujące wynosi co do zasady 14 dni. W treści aktu może zostać przewidziany termin dłuższy, możliwe jest również jego skrócenie, jeżeli ważny interes państwa wymaga jego natychmiastowego wejścia w życie i zasady demokratycznego państwa prawnego nie stoją temu na przeszkodzie. Przepisy porządkowe wchodzą w życie po upływie 3 dni od ich ogłoszenia z zastrzeżeniem, że termin ten może zostać skrócony, jeśli zwłoka w ich wejściu w życie mogłaby spowodować nieodwracalne szkody lub poważne zagrożenia życia, zdrowia lub mienia. W takich sytuacjach możliwe jest ich wejście w życie w dniu ich ogłoszenia.

\section{AKTY PRAWA MIEJSCOWEGO STANOWIONE PRZEZ GMINE}

O tym, jak istotną rolę polski ustawodawca przypisuje aktom prawa miejscowego świadczyć może to, że w każdej z ustaw samorządowych, w tym w ustawie o samorządzie gminnym z 8 marca 1990 r., poświęca im osobny rozdział. Co prawda, wspomniana ustawa odnosi się do aktów prawa miejscowego tylko w trzech artykułach (art. 40-42), jednakże reguluje materię podstawową. Ta pewna „oszczędność” prawodawcy może wynikać z faktu, iż funkcjonuje wiele aktów rangi ustawowej, które zawierają upoważnienia dla organów gminy do stanowienia aktów prawa miejscowego w konkretnych sprawach, w związku z czym bezzasadne wydaje się przytaczanie ich w treści samej ustawy.

Przepisy ustawy w art. 40 ust. 2 ustanawiają podstawę dla organów gminy do wydawania aktów prawa miejscowego w zakresie: wewnętrznego ustroju gminy oraz jednostek pomocniczych, organizacji urzędów i instytucji gminnych, zasad zarządu mieniem gminy oraz zasad i trybu korzystania z gminnych obiektów i urządzeń użyteczności publicznej. Do ich stanowienia upoważniona jest rada gminy, która czyni to w drodze uchwały (art. 41 ust. 1). Szczególnym rodzajem prawa miejscowego są przepisy porządkowe, które mogą być wydawane przez radę gminy, w zakresie nieuregulowanym w odrębnych ustawach lub innych przepisach powszechnie obowiązujących, jeśli jest to niezbędne dla ochrony życia lub zdrowia obywateli oraz dla zapewnienia porządku, spokoju i bezpieczeństwa publicznego 
(art. 40 ust. 3).Wymienione tu przesłanki mają charakter kumulatywny, muszą być spełnione łącznie, tylko wówczas istnieje możliwość wydawania przepisów porządkowych. Jeśli zostaną już wydane, za naruszenie norm porządkowych w nich zawartych może być przewidziana kara grzywny.

Jak już nadmieniono, zasadą ogólną jest, że to rada gminy jako organ stanowiący ustanawia akty prawa miejscowego. Jej rozstrzygnięcia podejmowane są w drodze uchwał. Ustawodawca nie zdefiniował na gruncie przepisów prawa samego pojęcia „uchwały”, jednakże A. i T. Szewc wskazują, że co do zasady będzie ona sposobem, formą wyrażenia woli jednostki samorządu terytorialnego. Istnieją jednak uchwały, których rolą nie jest wyrażanie rzeczywistej woli organu bądź też brak jest zależności w stosunku do tej woli. Warto podkreślić, że uchwała jako forma oświadczenia woli może być wykorzystywana jedynie przez organy kolegialne, w tym przypadku - radę gminy. Można ją dookreślić poprzez wskazanie na jej stanowiący charakter oraz fakt, że jest ustanawiana w celu rozstrzygania zagadnień poddanych pod obrady. Na ogół ma charakter konstytutywny, a więc jej przyjęcie wywołuje wiążące skutki. Zasada ta nie ma charakteru bezwzględnego ${ }^{13}$.

Biorąc pod uwagę okoliczności, w jakich wydawane są przepisy porządkowe, racjonalne wydaje się upoważnienie organu monokratycznego w osobie wójta, aby w przypadku niecierpiącym zwłoki, gdy rada gminy nie jest w stanie zebrać się na sesję w tak krótkim czasie, wydawał te przepisy w formie zarządzenia. $\mathrm{Z}$ drugiej zaś strony, zgodnie $\mathrm{z}$ art. 41 zarządzenie wójta podlega zatwierdzeniu na najbliższej sesji rady gminy. Traci ono moc w razie odmowy zatwierdzenia bądź jej nieprzedstawienia. W takiej sytuacji rada gminy określa termin utraty jego mocy obowiązującej. Można więc stwierdzić, iż kompetencje wójta w tym zakresie mają charakter „względny”, gdyż wydane przez niego przepisy porządkowe podlegają weryfikacji rady gminy ${ }^{14}$.

\section{BEZPIECZEŃSTWO EKOLOGICZNE GMINY}

Polska Konstytucja tylko raz posługuje się pojęciem „,bezpieczeństwa ekologicznego", stanowiąc w art. 74, że obowiązkiem władz publicznych jest prowadzenie polityki zapewniającej bezpieczeństwo ekologiczne współczesnemu i przyszłym pokoleniom. Częściej ustawa zasadnicza posługuje się natomiast pojęciem „ochro-

${ }^{13}$ A. Szewc, T. Szewc, Uchwałodawcza działalność organów samorządu terytorialnego, Warszawa: Difin 1999, s. 42-46.

${ }^{14}$ M. KaRPIUK, Przepisy porzadkowe jako szczególny rodzaj prawa miejscowego, „Studia Iuridicia Lublinensia" 4 (24) 2015, s. 30. 
ny środowiska", wymieniając ją już w art. 5 jako jedno z podstawowych zadań Rzeczypospolitej.

Polski prawodawca nie sformułował legalnej definicji „bezpieczeństwa ekologicznego", lukę tę uzupełnia jednak stosunkowo bogata literatura przedmiotu. Dla potrzeb niniejszej pracy należy zastanowić się, czym jest bezpieczeństwo ekologiczne z punktu widzenia nauki prawa ochrony środowiska. W tym ujęciu będą je tworzyć dwa podstawowe aspekty: zachowanie jednostki względem środowiska jako część obowiązków nakładanych przez prawo ochrony środowiska oraz pewien element wykorzystania przez władze publiczne instrumentów prawnych gwarantujących szeroko rozumiane prawo do środowiska. Owe instrumenty obejmują przede wszystkim system prawny danego państwa oraz normy prawa międzynarodowego ${ }^{15}$.

Na gruncie polskim jedna z pierwszych definicji została sformułowana w $1986 \mathrm{r}$. podczas Kongresu Intelektualistów w Warszawie. Wówczas to W. Michajłow przedstawiając pojęcie „bezpieczeństwa ekologicznego” zauważył, że jest ono znacznie bardziej precyzyjne niż „ochrona środowiska” i „ochrona środowiska naturalnego" albowiem znaczny poziom zanieczyszczeń spowodował, że w rzeczywistości jego stan naturalny już nie istnieje. Na przestrzeni lat pojawiło się wiele nowych sposobów definiowania bezpieczeństwa ekologicznego, niekiedy różniących się między sobą, w zależności od nauki i nurtu, jaki reprezentowali ich twórcy. Jeden z autorów, R. Paczuski włącza „bezpieczeństwo ekologiczne” do terminologii prawniczej z obszaru konstytucyjnych podstaw ochrony środowiska w Polsce. Jak wynika z zaproponowanej przez niego definicji, bezpieczeństwo to przekłada się na obowiązek władz publicznych do podejmowania działań ukierunkowanych na ochronę obywateli oraz przyszłych pokoleń. Ochrona ta dotyczy zagrożeń powstających $\mathrm{w}$ następstwie niewystarczającej harmonizacji rozwoju gospodarczego i społecznego z ochroną środowiska ${ }^{16}$

Rozważając korelację pomiędzy ochroną środowiska a bezpieczeństwem ekologicznym należy zwrócić uwagę, że trudno jest postawić między nimi znak równości. Działania podejmowane na rzecz środowiska nie mają bowiem wyłącznie charakteru ochronnego, ich celem jest również poprawa jego stanu i dbałość o jego rozwój. Można więc stwierdzić, że ochrona środowiska jest jednym z podstawowych, ale nie jedynym elementem, na którym opiera się bezpieczeństwo ekologiczne ${ }^{17}$. Jak zwraca uwagę J. Ciechanowicz-McLean, pojęcie bezpieczeństwa ekologicznego

${ }^{15}$ P. KoRzeniowsKi, Bezpieczeństwo ekologiczne jako instytucja prawna ochrony środowiska, Łódź: Wydawnictwo Uniwersytetu Łódzkiego 2012, s. 49, 52.

${ }^{16}$ Tamże, s. 58, 62.

${ }^{17}$ Konstytucja Rzeczypospolitej Polskiej. Komentarz, red. L. Garlicki, Warszawa: Wydawnictwo Sejmowe 2003, s. 3. 
jest szersze niż ochrona środowiska, a obowiązek władz publicznych zapewnienia tego bezpieczeństwa, ma raczej wymiar polityczny, a nie prawny. Bezpieczeństwo ekologiczne można określić jako stan charakteryzujący się brakiem zagrożeń dla środowiska, zaś sama ochrona środowiska bezspornie ma istotny wpływ na bezpieczeństwo ekologiczne ${ }^{18}$.

Samorząd gminny realizuje zadania mające na celu zapewnienie potrzeb społeczności lokalnej, w tym także w obszarze bezpieczeństwa ekologicznego. Dla zapewnienia bezpieczeństwa ekologicznego najistotniejsze będą m.in. sprawy ładu przestrzennego, gospodarki nieruchomościami, ochrony środowiska i przyrody oraz gospodarki wodnej, wodociągów i zaopatrzenia w wodę, kanalizacji, usuwania i oczyszczania ścieków komunalnych, utrzymania czystości i porządku oraz urządzeń sanitarnych, wysypisk i unieszkodliwiania odpadów komunalnych, ochrony zdrowia, zieleni gminnej i zadrzewień. Nie jest to katalog zamknięty o czym świadczy zastosowany przez ustawodawcę zwrot „w szczególności”.

WYBRANE GMINNE AKTY PRAWA MIEJSCOWEGO W OBSZARZE BEZPIECZEŃSTWA EKOLOGICZNEGO

Przepisy odnoszące się do bezpieczeństwa ekologicznego odnaleźć można w wielu aktach prawnych o różnym zakresie obowiązywania. W. Kitler dokonuje podziału źródeł prawa regulujących problematykę bezpieczeństwa ekologicznego na dwie zasadnicze grupy: normy prawne zawarte w aktach prawa międzynarodowego, w tym unijnego oraz prawo krajowe bezpieczeństwa ekologicznego. W tym ujęciu, dodatkowo wskazuje on na mieszczące się w prawie krajowym przepisy: regulujące ochronę dziedzictwa przyrodniczego i racjonalne użytkowanie zasobów przyrody, regulujące zrównoważone wykorzystanie surowców, materiałów, wody i energii, regulujące działania na rzecz poprawy jakości środowiska i bezpieczeństwa ekologicznego, służące realizacji przedsięwzięć na rzecz przeciwdziałania zmianom klimatu, prawo karne oraz prawo wspierające ${ }^{19}$.

Prawo stanowi podstawę, na której opiera się cała działalność władz publicznych. $\mathrm{W}$ literaturze istnieją liczne opracowania dotyczące funkcji prawa, interesujące jest natomiast ujęcie proponowane przez R. Paczuskiego, który odnosi je konkretnie do prawa ochrony środowiska. Według Autora katalog ten tworzy siedem głównych

18 J. Ciechanowicz-McLean, Prawo i polityka ochrony środowiska, Warszawa: Oficyna a Wolters Kluwer business 2009, s. 60.

${ }^{19}$ W. KitLer, Bezpieczeństwo narodowe RP. Podstawowe kategorie, uwarunkowania, system, Warszawa: Akademia Obrony Narodowej 2011, s. 171-172. 
funkcji: organizacyjna, reglamentacyjno-ochronna, ochrony praw podmiotowych, stymulatora działalności gospodarczej, wdrażania postępu technicznego, represyjna i ochrony walorów środowiska o znaczeniu ponadpaństwowym ${ }^{20}$.

Organy samorządu terytorialnego w wyniku procesów decentralizacyjnych otrzymują coraz szersze uprawnienia w zakresie prawa ochrony środowiska. Działanie to wynika ze szczególnego umiejscowienia struktur samorządowych w strukturach administracji publicznej. Jako instytucja znajdująca się najbliżej obywatela, samorząd potrafi najlepiej rozpoznać lokalne potrzeby oraz skutecznie zastosować instrumenty prawa ochrony środowiska ${ }^{21}$. Nie byłoby to jednak możliwe bez wykorzystania prawa miejscowego, które doprecyzowuje konkretne rozwiązania z uwzględnieniem specyfiki danego obszaru.

Mimo istotnej roli, jaką pełnią akty prawa miejscowego i ich stosunkowo szerokiego uregulowania w Konstytucji oraz ustawach samorządowych, jak zwraca uwagę H. Izdebski wciąż brakuje jednak regulacji, które wskażą jasno, jaką materię muszą one zawierać, aby zaliczyć je do tej kategorii źródeł prawa. Co prawda, dylematy te rozstrzyga w pewnej mierze orzecznictwo Naczelnego Sądu Administracyjnego, Trybunału Konstytucyjnego i Sądu Najwyższego, jednakże powinny zostać one wyjaśnione w sposób całościowy. Należy podkreślić, że spośród wielu uchwał stanowionych przez gminę, jak również pozostałe organy jednostek samorządu terytorialnego, nie wszystkie spełniają kryteria przewidziane dla aktów prawa miejscowego. Wskazane jest więc opracowanie operacyjnej teorii takich aktów, która pozwoli choć w pewnym stopniu rozwiązać ten problem ${ }^{22}$.

\section{ZAGOSPODAROWANIE PRZESTRZENNE}

Mając na uwadze zadania realizowane przez gminę oraz jej obowiązek dbałości o stan środowiska, należy wskazać na akty prawa miejscowego stanowione w obszarze zagospodarowania przestrzennego. Główny instrument stanowią tutaj plany zagospodarowania przestrzennego, opracowywane dla gminy bądź jej części czy też zespołu gmin lub ich części. Za przygotowanie projektu planu odpowiedzialny jest wójt, burmistrz, prezydent miasta, a uchwalany jest on przez radę gminy ${ }^{23}$.

\footnotetext{
${ }^{20}$ R. PAczuski, Prawo ochrony środowiska, Bydgoszcz: Oficyna Wydawnicza Branta 2000, s. 56.

${ }^{21}$ B. WierzBowski, B. Rakoczy, Podstawy prawa ochrony środowiska, Warszawa: LexisNexis 2007, s. $41-42$.

${ }^{22}$ H. IzDEBsKI, Samorząd terytorialny. Podstawy ustroju i działalności, Warszawa: LexisNexis 2011, s. 400-407.

${ }^{23}$ J. OnIszczuk, Samorzad Terytorialny w orzecznictwie Trybunału Konstytucyjnego, Warszawa: Dom Wydawniczy ABC 2002, s. 114.
} 
Przy sporządzaniu planów organy gminy są zobowiązane kierować się zasadą zrównoważonego rozwoju i ochrony środowiska. Należy w nich uwzględnić w szczególności: rozwiązania niezbędne do zapobiegania powstawaniu zanieczyszczeń, zapewnienia ochrony przed powstającymi zanieczyszczeniami oraz przywracania środowiska do właściwego stanu, jak również ustalać warunki realizacji przedsięwzięć w taki sposób, aby uzyskać optymalne efekty w zakresie ochrony środowiska. Przeznaczenie i sposób zagospodarowania terenu powinny w jak największym stopniu zapewniać zachowanie jego walorów krajobrazowych (art. 71 ustawy prawo ochrony środowiska). Wskazany przepis należy interpretować mając na względzie ustawę o samorządzie gminnym i ustawę o planowaniu i zagospodarowaniu przestrzennym ${ }^{24}$.

Szczegółowe regulacje dotyczące planów zagospodarowania przestrzennego przewiduje ustawa z dnia 27 marca 2003 roku o planowaniu i zagospodarowaniu przestrzennym. W myśl jej przepisów wszelkie czynności, tj. zakres i sposoby postępowania $\mathrm{w}$ sprawach przeznaczania terenów na określone cele oraz ustalania zasad ich zagospodarowania i zabudowy powinny następować w oparciu o ład przestrzenny i zrównoważony rozwój (art. 1 pkt 2). Ponadto, zgodnie z art. 1 ust. $2 \mathrm{w}$ planowaniu i zagospodarowaniu przestrzennym powinno uwzględniać się, m.in. wymagania ładu przestrzennego, walory architektoniczne i krajobrazowe, wymagania ochrony środowiska, w tym gospodarowania wodami i ochrony gruntów rolnych i leśnych. Pod pojęciem „zrównoważonego rozwoju”, zgodnie z ustawą z dnia 27 kwietnia 2001 roku prawo ochrony środowiska, należy rozumieć taki rozwój społeczno-gospodarczy, w którym następuje proces integrowania działań politycznych, gospodarczych i społecznych, z zachowaniem równowagi przyrodniczej oraz trwałości podstawowych procesów przyrodniczych, w celu zagwarantowania możliwości zaspokajania podstawowych potrzeb poszczególnych społeczności lub obywateli zarówno współczesnego pokolenia, jak i przyszłych pokoleń.

W miejscowych planach zagospodarowania przestrzennego gmina określa przeznaczenie terenu, rozmieszczenie inwestycji celu publicznego oraz sposoby zagospodarowania i warunki zabudowy. Należy pamiętać, że plan ma charakter fakultatywny, a w razie jego nieuchwalenia określenie sposobów zagospodarowania i warunków zabudowy terenu następuje w drodze decyzji o warunkach zabudowy i zagospodarowania terenu (art. 4 ustawy o planowaniu i zagospodarowaniu przestrzennym).Cele środowiskowe zajmują także istotne miejsce $\mathrm{w}$ studiach uwarunkowań i kierunków zagospodarowania przestrzennego, jednakże w związku z tym, iż studia te nie są aktami prawa miejscowego, nie będą stanowiły przed-

${ }^{24}$ E. Radziszewski, Prawo ochrony środowiska. Przepisy i komentarz, Warszawa: Wydawnictwo Prawnicze LexisNexis 2003, s. 113. 
miotu niniejszego opracowania. Odmiennie przedstawia się sytuacja, jeśli chodzi o miejscowe plany zagospodarowania przestrzennego, gdyż ustawodawca $\mathrm{w}$ art.14 pkt 8 ustawy precyzuje, że plany te należą do aktów prawa miejscowego.

$\mathrm{W}$ miejscowym planie zagospodarowania przestrzennego obowiązkowo przedstawia się, m.in. zasady ochrony środowiska, przyrody i krajobrazu oraz minimalny udział procentowy powierzchni biologicznie czynnej w odniesieniu do powierzchni działki budowlanej. Regulacje ustawy o planowaniu i zagospodarowaniu przestrzennym uzupełnia $\mathrm{w}$ art. 71-73 ustawa prawo ochrony środowiska, określając konkretne rozwiązania z zakresu ochrony środowiska, jakie powinno uwzględniać się w aktach planowania przestrzennego. Istotne jest, że rozwiązania te nie mogą mieć charakteru ogólnego i stanowić wyłącznie powtórzenia materii ustawowej. Powinny być one dookreślone i umożliwić realizację na danym terenie celów przewidzianych planem. Przepis art. 74 nakłada również obowiązek zapewnienia oszczędnego korzystania $\mathrm{z}$ terenu $\mathrm{w}$ procesach planistycznych ${ }^{25}$. Dodatkowo, opracowywana jest także prognoza oddziaływania na środowisko, dokument o charakterze informacyjnym, niewiążący i nie włączany do planu.

\section{OCHRONA PRZYRODY}

Akty prawa miejscowego odgrywają ważną rolę w ochronie środowiska, a szczególnie w ochronie przyrody. Wzrost ich znaczenia uwarunkowany jest zwiększającą się rolą samorządu terytorialnego oraz postępującą decentralizacją i dekoncentracją. Rada gminy realizując swoje ustawowe zadania w zakresie ochrony przyrody jest uprawniona, m.in. do ustanawiania i znoszenia form ochrony przyrody ${ }^{26}$.

Ustawa o samorządzie gminnym nie wskazuje wprost na kompetencje rady gminy do stanowienia uchwał w zakresie ochrony przyrody, zastrzega jednak w art. 18 ust. 2 pkt 15, że należy do niej stanowienie w innych sprawach zastrzeżonych ustawami do kompetencji rady gminy Zgodnie z art. 44 ustawy z dnia 16 kwietnia 2004 roku o ochronie przyrody, ustanowienie pomnika przyrody, stanowiska dokumentacyjnego, użytku ekologicznego lub zespołu przyrodniczo-krajobrazowego następuje w drodze uchwały rady gminy. Uchwała ta określa nazwę danego obiektu lub obszaru, jego położenie, sprawującego nadzór, szczególne cele ochrony, w razie potrzeby ustalenia dotyczące jego czynnej ochrony oraz zakazy właściwe dla tego obiektu, obszaru lub jego części. Obowiązkiem rady przy podejmowaniu uchwały w sprawie ustanowienia zespołu przyrodniczo-krajobrazowego jest uwzględnienie

${ }^{25}$ Prawo ochrony środowiska, red. J. Stelmasiak, Warszawa: LexisNexis 2009, s. 408-413.

${ }^{26}$ B. Rakoczy, Prawo ochrony przyrody, Warszawa: Wydawnictwo C.H. Beck 2009, s. 27. 
istniejących na tym terenie obszarów parków kulturowych. Uchwały wymagają uzgodnienia $\mathrm{z}$ właściwym regionalnym dyrektorem ochrony środowiska. W razie konieczności zniesienia formy ochrony przyrody także dokonuje tego w drodze uchwały rada gminy, a zniesienie to może nastąpić w razie utraty wartości przyrodniczych i krajobrazowych, ze względu na które ustanowiono formę ochrony przyrody, lub w razie konieczności realizacji inwestycji celu publicznego w przypadku braku rozwiązań alternatywnych lub zapewnienie bezpieczeństwa powszechnego. Zniesienie zespołu przyrodniczo-krajobrazowego następuje również w przypadku ustanowienia parku kulturowego.

\section{UTRZYMANIE CZYSTOŚCI I PORZĄDKU W GMINIE}

Utrzymanie czystości i porządku w gminie należy do jej zadań własnych, o czym stanowi art. 7 ust. 1 pkt 3 ustawy o samorządzie gminnym oraz art. 3 ust. 1 ustawy z dnia 13 września 1996 r. o utrzymaniu czystości i porządku w gminach. Aktem prawa miejscowego $\mathrm{w}$ gminie określającym szczegółowe działania w tym zakresie jest, zgodnie z art. 4 ust. 1 drugiej z wymienionych ustaw „Regulamin utrzymania czystości i porządku w gminie”, uchwalany przez radę gminy, po zasięgnięciu opinii państwowego powiatowego inspektora sanitarnego. Ustawodawca $\mathrm{w}$ art. 4 ust. 2 konkretyzuje wymagania co do treści Regulaminu stanowiąc, że określa on szczegółowe zasady utrzymania czystości i porządku na terenie gminy dotyczące: 1) wymagań w zakresie utrzymania czystości i porządku na terenie nieruchomości obejmujących: a) prowadzenie selektywnego zbierania i odbierania lub przyjmowania przez punkty selektywnego zbierania odpadów komunalnych lub zapewnienie przyjmowania $\mathrm{w}$ inny sposób co najmniej takich odpadów komunalnych jak: przeterminowane leki i chemikalia, zużyte baterie i akumulatory, zużyty sprzęt elektryczny i elektroniczny, meble i inne odpady wielkogabarytowe, zużyte opony, odpady zielone oraz odpady budowlane i rozbiórkowe stanowiące odpady komunalne, a także odpadów komunalnych określonych w przepisach wydanych na podstawie art. 4a; b) uprzątanie błota, śniegu, lodu i innych zanieczyszczeń z części nieruchomości służących do użytku publicznego; c) mycie i naprawy pojazdów samochodowych poza myjniami i warsztatami naprawczymi;

2) rodzaju i minimalnej pojemności pojemników przeznaczonych do zbierania odpadów komunalnych na terenie nieruchomości oraz na drogach publicznych, warunków rozmieszczania tych pojemników i ich utrzymania w odpowiednim stanie sanitarnym, porządkowym i technicznym, przy uwzględnieniu: a) średniej ilości odpadów komunalnych wytwarzanych w gospodarstwach domowych bądź w innych źródłach; b) liczby osób korzystających z tych pojemników; 
3) częstotliwości i sposobu pozbywania się odpadów komunalnych i nieczystości ciekłych $\mathrm{z}$ terenu nieruchomości oraz z terenów przeznaczonych do użytku publicznego;

4) innych wymagań wynikających z wojewódzkiego planu gospodarki odpadami;

5) obowiązków osób utrzymujących zwierzęta domowe, mających na celu ochronę przed zagrożeniem lub uciążliwością dla ludzi oraz przed zanieczyszczeniem terenów przeznaczonych do wspólnego użytku;

6) wymagań utrzymywania zwierząt gospodarskich na terenach wyłączonych z produkcji rolniczej, w tym także zakazu ich utrzymywania na określonych obszarach lub w poszczególnych nieruchomościach;

7) wyznaczania obszarów podlegających obowiązkowej deratyzacji i terminów jej przeprowadzania.

Rada gminy zobowiązana jest dostosować regulamin do wojewódzkiego planu gospodarki odpadami w terminie 6 miesięcy od dnia uchwalenia tego planu (art. 4 ust. 3).

Regulaminy wprowadzając przepisy powszechnie obowiązujące na danym obszarze, obligują jego mieszkańców do ich zastosowania, co nie zawsze spotyka się z aprobatą lokalnej społeczności, jak również innych organów administracji publicznej. Niekiedy zwraca się uwagę na nieprawidłowości pojawiające się w aktach prawa miejscowego, które mogą wynikać $\mathrm{z}$ braku zaplecza prawnego $\mathrm{w}$ danej jednostce samorządowej. Ustawa o utrzymaniu czystości i porządku w gminach wskazuje katalog obligatoryjnych elementów, które muszą znaleźć się w Regulaminie, a jednocześnie wyznacza granice kompetencji uchwałodawczej rady gminy. W dniu 31 lipca 2015 r. Rada Miejska Węglińca przyjęła uchwałę Nr 104/IX/14 w sprawie regulaminu utrzymania czystości i porządku na terenie Gminy i Miasta Węgliniec. Uchwała ta stała się przedmiotem skargi wniesionej do Wojewódzkiego Sądu Administracyjnego we Wrocławiu przez wojewodę dolnośląskiego będącego organem nadzoru nad działalnością samorządu terytorialnego. Skarżący wnosił o stwierdzenie nieważności uchwały w całości podnosząc, iż § 3 ust. 2 regulaminu stanowiący o obowiązku ,uprzątania błota, śniegu, lodu i innych zanieczyszczeń z chodników, polegające na: a) Uprzątaniu niezwłocznie po opadach: błota, śniegu, lodu z powierzchni chodników, a także części nieruchomości pelniących funkcje komunikacyjne, np. podwórzy, przejść, bram itp. [...]" jest sprzeczny z postanowieniami ustawy o utrzymaniu czystości i porządku w gminach. Wojewoda zwrócił uwagę, że ,jednym z obligatoryjnych elementów regulaminu utrzymania czystości i porządku na terenie gminy jest określenie szczegółowych zasad dotyczących wymagań w zakresie utrzymania czystości i porządku na terenie nieruchomości obejmujących uprzątanie błota, śniegu, lodu i innych zanieczyszczeń z części nieruchomości służących do użytku publicznego. Postanowienie uchwały dotyczy 
natomiast uprzątnięcia chodników, który to obowiązek w literze a został również rozciągnięty na części nieruchomości pełniące funkcje komunikacyjne. [...] Ponadto, pojęcie to nie jest równoznaczne z pojęciem nieruchomości służących do użytku publicznego, ich zakresy znaczeniowe nie są bowiem tożsame. Także próba definiowania nieruchomości pełniących funkcje komunikacyjne poprzez otwarte wyliczenie «np. podwórzy, przejść, bram itp.» nie spełnia wymogów kompletnego wypełnienia upoważnienia ustawowego, a ponadto narusza zasadę prawidłowej legislacji”"27. Powyższy przykład nie ma charakteru jednostkowego, zjawisko niedostosowania Regulaminów do wymogów przewidzianych ustawą, przekroczenia przez radę gminy swoich uprawnień jest niestety znacznie częstsze. Trudno jest upatrywać w nim pozytywnego wpływu na bezpieczeństwo ekologiczne gminy poprzez nałożenie na mieszkańców dodatkowych obowiązków czy wprowadzenie dodatkowych zakazów, albowiem może to odnieść skutek zgoła odwrotny.

\section{ZAKOŃCZENIE}

Stanowienie przez gminy aktów prawa miejscowego daje im możliwość decydowania, oczywiście w granicach określonych prawem, nie tylko o tym, jak będą funkcjonowały, ale także, jakie będą podejmowały działania na rzecz ochrony pewnych wartości. Do dóbr mieszczących się w pojęciu owych „wartości” zaliczać się będzie niewątpliwie czyste, wolne od zagrożeń środowisko, którym będą mogły się cieszyć zarówno obecne, jak i przyszłe pokolenia. Gmina odgrywa szczególną rolę $\mathrm{w}$ wykonywaniu zadań lokalnych, gdyż to ją ustawodawca uczynił podstawową jednostką samorządu terytorialnego. Stanowione przez nią prawo reguluje wiele ważnych aspektów życia społeczności lokalnej, począwszy od zagospodarowania przestrzennego, ochronę przyrody, z utrzymaniem czystości i porządku włącznie. Wymienione obszary mają charakter jedynie przykładowy, a każdy z nich zawiera w sobie szeroki katalog obowiązków i zadań związanych z bezpieczeństwem ekologicznym. Stanowione przez organy gminy przepisy powinny być zgodne z innymi źródłami prawa oraz spełniać wszystkie wymogi „zasad techniki prawodawczej”. Jak pokazuje orzecznictwo sądów administracyjnych wymóg ten nie zawsze jest realizowany. Samo nazewnictwo przepisów gminnych również nie jest do końca jasne, albowiem nie wszystkie akty stanowione przez organy gminy, a noszące nazwę „uchwały”, są aktami prawa miejscowego. Przyjęcie takiego rozwiązania może nastręczać pewnych trudności związanych z ich praktycznym zastosowaniem.

${ }^{27}$ Wyrok Wojewódzkiego Sądu Administracyjnego we Wrocławiu z dnia 2 marca 2016 r., sygn. II SA/Wr 864/15. 
W samej literaturze przedmiotu można spotkać różne klasyfikacje tych samych aktów, raz przydające im walor aktu prawa miejscowego, innym razem - odbierające. Przykładem może być tu chociażby „Regulamin utrzymania czystości i porządku w gminie". Warto byłoby poddać pod zastanowienie, jak zasugerował H. Izdebski, wypracowanie operacyjnej teorii takich aktów, co poprawiłoby przejrzystość prawa miejscowego i ułatwiło jego stosowanie.

Obowiązek zapewnienia bezpieczeństwa ekologicznego ciąży nie tylko na władzach gminy ale przede wszystkim na jej mieszkańcach, którzy poprzez swoją działalność znacząco wpływają na stan środowiska. Warto mieć na uwadze, że instrument, jakim jest możliwość stanowienia przepisów gminnych, choć tak istotny, powinien być wspierany przez inne, pozaprawne formy działań na rzecz bezpieczeństwa ekologicznego.

\section{BIBLIOGRAFIA}

\section{ŹRÓDŁA PRAWA}

Konstytucja Rzeczypospolitej Polskiej z dnia 2 kwietnia 1997 r., Dz. U. Nr 78, poz. 483 z późn. zm. Ustawa z dnia 8 marca 1990 r. o samorządzie gminnym, Dz. U. Nr 16, poz. 95 z późn. zm.

Ustawa z dnia 13 września 1996 r. o utrzymaniu czystości i porządku w gminach, Dz. U. Nr 132, poz. $622 \mathrm{z}$ późn. zm.

Ustawa z dnia 20 lipca 2000 r. o ogłaszaniu aktów normatywnych i niektórych innych aktów prawnych, Dz. U. Nr 62, poz. 718 z późn. zm.

Ustawa z dnia 27 kwietnia 2001 r. prawo ochrony środowiska, Dz. U. Nr 62, poz. 627 z późn. zm. Ustawa z dnia 27 marca 2003 r. o planowaniu i zagospodarowaniu przestrzennym, Dz. U. Nr 80, poz. 717 z późn. zm.

Ustawa z dnia 16 kwietnia 2004 r. o ochronie przyrody, Dz. U. Nr 92, poz. 880 z późn. zm.

\section{ORZECZNICTWO}

Wyrok Trybunału Konstytucyjnego z dnia 8 lipca 2003 r., sygn. akt P10/02, poz. 62.

Wyrok Wojewódzkiego Sądu Administracyjnego we Wrocławiu z dnia 2 marca 2016 r., sygn. II SA/Wr 864/15.

\section{LITERATURA}

Bandarzewski Kazimierz, Chmielnicki Paweł, Kisiel Wiesława: Prawo samorządu terytorialnego w Polsce, Warszawa: Wydawnictwo Prawnicze LexisNexis 2006.

BARon-WiatereK Małgorzata: Prawo miejscowe jako podstawa funkcjonowania społeczności lokalnej - wybrane aspekty, Zeszyty Naukowe Politechniki Ślaskiej 76 (2014), s. 189-198.

Ciechanowicz-McLean Janina: Prawo i polityka ochrony środowiska, Warszawa: Oficyna a Wolters Kluwer business 2009.

DĄBEK Dorota: Prawo miejscowe samorządu terytorialnego, Bydgoszcz-Kraków: Oficyna Wydawnicza Branta 2003. 
Doganowski Roman: Ustrój i zadania samorządu terytorialnego, Sulechów: Wyższa Szkoła Zawodowa Administracji Publicznej w Sulechowie 2001.

DoLNICKI Bogdan: Samorząd terytorialny, Warszawa: Lex a Wolters Kluwer business 2012.

IZDEBSKI Hubert: Samorząd terytorialny. Podstawy ustroju i działalności, Warszawa: LexisNexis 2011.

KARPIUK Mirosław: Przepisy porządkowe jako szczególny rodzaj prawa miejscowego, Studia Iuridicia Lublinensia 4 (24) 2015, s. 21-34.

Kisiel Wiesława: Ustrój samorządu terytorialnego w Polsce, Warszawa: Wydawnictwo Prawnicze LexisNexis 2003.

KITLER Waldemar: Bezpieczeństwo narodowe RP. Podstawowe kategorie, uwarunkowania, system, Warszawa: Akademia Obrony Narodowej 2011.

Konstytucja Rzeczypospolitej Polskiej. Komentarz, red. L. Garlicki, Warszawa: Wydawnictwo Sejmowe 2003.

KoRZENIOwski Piotr: Bezpieczeństwo ekologiczne jako instytucja prawna ochrony środowiska, Łódź: Wydawnictwo Uniwersytetu Łódzkiego 2012.

Niewiadomski Zygmunt: Geneza i istota samorządu terytorialnego. Przekształcenia instytucji, [w:] http://www.wspia.eu/file/15731/15-niewiadomski_pl.pdf [dostęp: 8.04.2019].

OnIszczuK Jerzy: Samorząd Terytorialny w orzecznictwie Trybunału Konstytucyjnego, Warszawa: Dom Wydawniczy ABC 2002.

Paczuski Ryszard: Prawo ochrony środowiska, Bydgoszcz: Oficyna Wydawnicza Branta 2000.

Prawo ochrony środowiska, red. J. Stelmasiak, Warszawa: LexisNexis 2009.

RAdziszewski Edward: Prawo ochrony środowiska. Przepisy i komentarz, Warszawa: Wydawnictwo

Prawnicze LexisNexis 2003.

Rakoczy Bartosz: Prawo ochrony przyrody, Warszawa: Wydawnictwo C.H. Beck 2009.

Skrzydıo Wiesław: Konstytucja Rzeczypospolitej Polskiej. Komentarz, Warszawa: Oficyna a Wolters Kluwer business 2009.

SzEwC Andrzej, Szewc Tomasz: Uchwałodawcza działalność organów samorządu terytorialnego, Warszawa: Difin 1999.

Ustrój samorządu terytorialnego w Polsce, red. M. Chmaj, Warszawa: Wydawnictwo Prawnicze LexisNexis 2007.

WierzBowski Błażej, Rakoczy Bartosz: Podstawy prawa ochrony środowiska, Warszawa: LexisNexis 2007.

Winczorek Piotr: Komentarz do Konstytucji Rzeczypospolitej Polskiej z dnia 2 kwietnia 1997 roku, Warszawa: Liber 2008.

\section{AKTY PRAWA MIEJSCOWEGO W GMINIE I ICH ZNACZENIE DLA BEZPIECZEŃSTWA EKOLOGICZNEGO}

\section{Streszczenie}

Akty prawa miejscowego należą do źródeł prawa powszechnie obowiązującego na określonym obszarze. Przedmiotem ich regulacji jest wiele aspektów życia społeczności lokalnej, w tym działania na rzecz zapewnienia bezpieczeństwa ekologicznego. Szczególną rolę przypisuje się tu gminie, jako podstawowej jednostce samorządu terytorialnego. Stanowione przez nią prawo dostosowane jest do specyfiki danej gminy, przez co jest ważnym instrumentem realizacji jej potrzeb i wymagań.

Słowa kluczowe: gmina; samorząd terytorialny; akty prawa miejscowego; bezpieczeństwo ekologiczne 


\title{
ACTS OF LOCAL LAW IN THE MUNICIPALITY AND THEIR MEANING FOR ECOLOGICAL SECURITY
}

\begin{abstract}
Su m mary
Local law acts are a source of law generally applicable in a particular area. The subject of their regulation covers many aspects of local community life, including ecological security. A particular role is attributed to the municipality, as the basic unit of local government. The law is tailored to the specific nature of the municipality and is therefore an important instrument for meeting its needs and requirements.
\end{abstract}

Key words: municipality; local government; acts of local law; ecological security 